Gadjah Mada International Journal of Business

September 2004, Vol. 6, No. 3, pp. 323-334

\title{
PERCEPTION \\ OF PROFESSIONAL ENGINEERS TOWARD QUALITY OF WORKLIFE AND ORGANIZATIONAL COMMITMENT A Case Study
}

\author{
Razali Mat Zin
}

This empirical investigation was aimed to determine the pattern of the relationships between the perceived presence of quality of worklife ( $Q W L)$ factors and organizational commitment using samples from professional engineers in Malaysia. Engineers in private sector were selected to participate in this study. A total of 250 sets of questionnaires were sent to the selected organizations, and 152 useable questionnaire representing a response rate of $60.8 \%$ were used for statistical analysis. A QWL measure consisting of seven factors: growth and development, participation, physical environment, supervision, pay and benefit, social relevance, and workplace integration was developed based on Walton's (1974) conception. The three-component model and measure of organizational commitment developed by Allen and Meyer (1990) was adopted in this study. Results of regression analysis indicated that only two $Q W L$ factors, growth and development and pay and benefit, were significant in explaining organizational commitment. Implication and suggestions for further research are also discussed.

Keywords: affective; continuance; normative; organizational commitment; professional engineers; quality of worklife 


\section{Introduction}

Interest in the quality of worklife (QWL) as a management technique has become widespread in Malaysian private sector organizations in recent years. The concern for quality of worklife (QWL) in the workplace has been articulated in management thought since McGregor (1960) introduced Theory $X$ and Theory $Y$ to describe two styles of management. Managers who subscribe to Theory $X$ believe that workers in general are lazy, dislike responsibility, are self-centered and are strictly motivated by extrinsic rewards. Therefore managers should devote their energy toward directing and controlling people. In contrast, Theory $Y$ managers believe that workers are inherently not lazy and self-centered. Workers can enjoy responsibility and are motivated by intrinsic rewards, such as self-esteem, belongingness, social recognition and selfactualization. Managers who subscribe to the assumptions of Theory $Y$ focus their efforts to facilitate the achievement of both the workers' and the organizational goals.

The phrase "quality of worklife" was first introduced in the United States in the late 1960's to address the problems of poor quality of life at the work place (Davis 1977). The concern with quality of worklife originated from a series of studies carried out by Trist and his co-workers at the Tavistock Institute in London. The findings of these studies served as the foundations for socio-technical systems theory on which many current efforts to reform work organizations are based (Huse and Cummings 1985).

Since the meaning attributed the term has undergone considerable change and development (Huse and Cummings 1985) a variety of concepts have been used to map out the conditions of QWL. Earlier, the term referred to morale and later to human relations, organization development, redesign of work systems and industrial democracy (Sayeed and Sinha 1981).

\section{Objective of the Study}

In Malaysia, employers are becoming increasingly concerned with the cost of work disruption, turnover, absenteeism and poor morale among employees. In recent years, various attempts have been made to integrate workers into the organization, attack the problems of alienation and improve the quality of worklife in organizations.

This study was conducted to examine the nature of relationships between the perceived presence of QWL factors and organizational commitment using samples from private sector engineers in Malaysia.

\section{Related Literature}

\section{Quality of Worklife}

A review of the literature on the concept of QWL was carried out to determine the appropriate concepts to be included in the questionnaire. The approach taken in this study was to view QWL in terms of perceived organizational conditions, as opposed to other views which regard QWL as either intervention strategies for organizational improvements (e.g. Gowdy 1988) or as an institutional approach in creating workplace democracy (Maccoby 1984). Though the approach taken was from the perspective of perceived organizational conditions, the basic philosophy of QWL which regards employees as capable of learning (Camman 1984) and organizations as learning environments (Cherns and Davis 1975) was given due consideration in constructing the questionnaire. 


\section{Zin-Perception of Professional Engineers toward Quality of...}

A dominant approach taken in previous studies on QWL was to regard job satisfaction as a measure of QWL. Wilcock and Wright (1991) remarked that the use of job satisfaction as a measure of QWL has its limitations, because satisfaction is only one of the many aspects of QWL (White 1981; Davis and Cherns 1975). Since a satisfactory measure of QWL suitable for adoption in this study was not available in the literature, and in order to avoid using job satisfaction as a single indicator of QWL, a set of questionnaires purporting to measure the concept had to be developed.

In this study, the conceptual categories proposed by Walton (1974) were adopted as the basis for designing the QWL measure. Walton provided eight aspects in which employees' perceptions toward their work organizations could determine their QWL: adequate and fair compensation; safe and healthy environment; development of human capacities; growth and security; social integration; constitutionalism; the total life space; and social relevance. To avoid the questionnaire being too long, the researcher decided to reduce the number of factors from eight to seven, and also to make some modifications in the naming of the factors.

The factor constitutionalism, which refers to "respect accorded to employees" and "the opportunity for employees to voice out their opinions" (Walton 1974), was changed to supervision. In the context of non-supervisory employees, especially in Malaysia where power distance is high, there is a set procedure for employees to voice their opinions in the workplace. Employees are required to use proper channels in expressing their opinions, i.e. in most cases, through their immediate supervisors. It is therefore appropriate that the items relating to the quality of relationship between a subordinate and his/her supervisor should be included as a measure of QWL.

The factor, development of human capacities, which refers to "the opportunity for employees to perform work which is meaningful" is replaced with participation. Again, in the context of lower level employees, it may be quite difficult for them to judge the "meaningfulness" of their jobs because "meaningfulness," especially in Malaysia, is often based on amount of monthly salary the job holder receives. Participation has been considered as a key element in Nadler and Lawler's (1983) working definition of QWL because participation can cause people to work better: employees who are allowed to be involved in decisions relating to their jobs will develop certain interpersonal and analytical skills, thus enhancing their sense of meaningfulness.

Walton's factor, total life space was not included in the QWL questionnaire for this study. This was to avoid redundancy because Walton's definition of total life space as a "balance between work and non-work" was thought to be adequately represented in another factor, social relevance.

\section{Selection of Items}

Having defined the factors representing the construct of QWL, the subsequent step in the development of a QWL measure involved the selection of items to represent the respective factors. In searching for appropriate items, we referred to various published sources in the literature. Items were collected from various scales that were thought to represent the defined dimensions of QWL. The items and the sources are presented in Table 1. 
Gadjah Mada International Journal of Business, September 2004, Vol. 6, No. 3

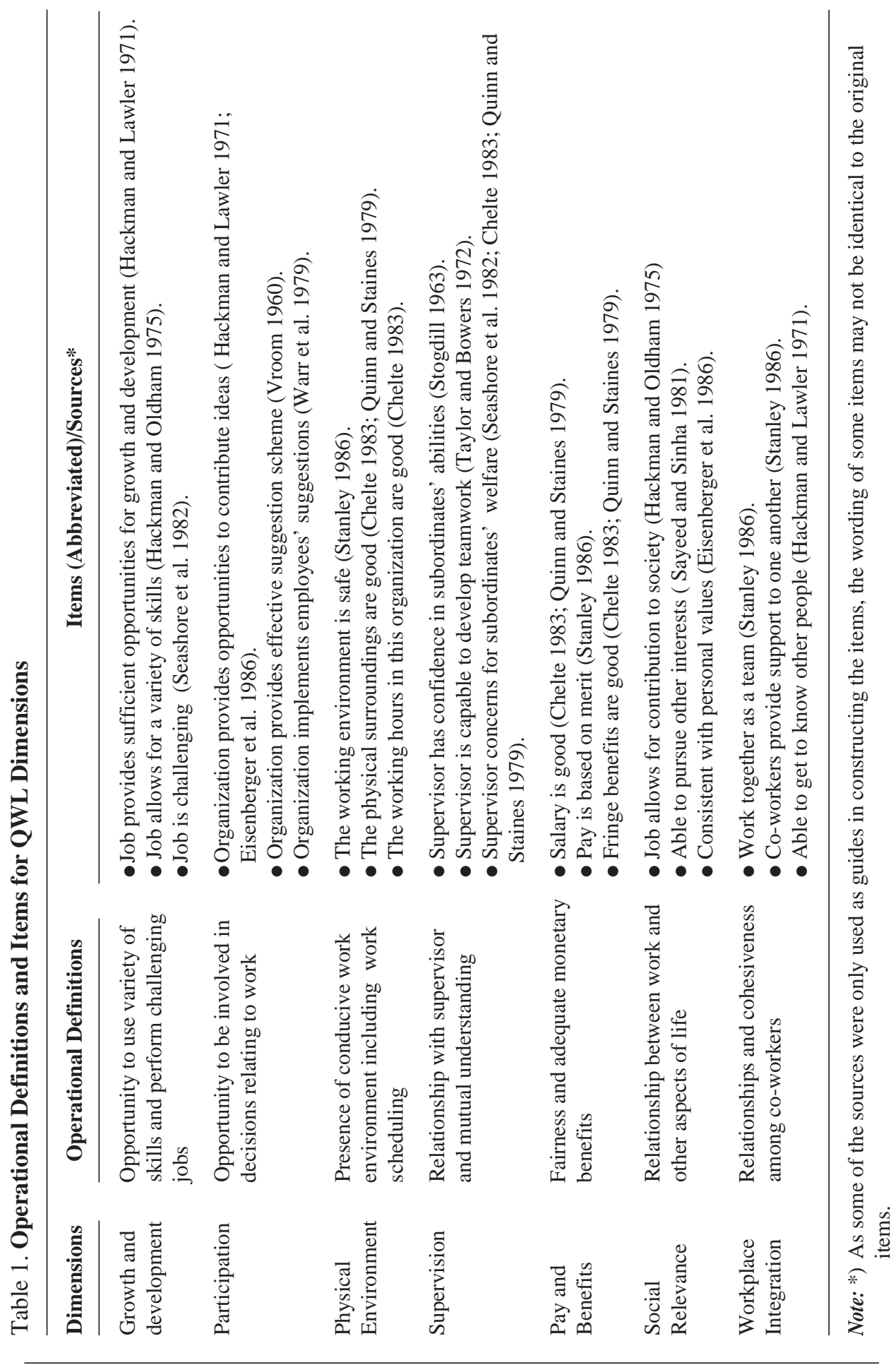


Zin -Perception of Professional Engineers toward Quality of...

\section{Organizational Commitment}

The organizational commitment measure adopted for this study was the one developed by Allen and Meyer (1990). Allen and Meyer (1990) noted that, although several conceptualizations of attitudinal commitment have appeared in the literature, each reflects one of three general themes: affective, perceived cost, and obligation. Based on these general theme, Allen and Meyer conceptualized organizational commitment in terms of three distinct dimensions: affective, continuance, and normative.

Affective commitment is characterized by the presence of emotional attachment to the organization such that the affectively committed individual identifies with, is involved in, and enjoys membership in, the organization (Allen and Meyer 1990). The affectively committed employees remain with the organization because they want to (Meyer et al. 1990).

The continuance dimension of commitment combines a behavioral conceptualization (disinclination to leave the organization) with an instrumental cause (potential costs and lack of alternatives) (Popper and Lipshitz 1992). Employees whose primary link to the organization is based on continuance commitment remain because they need to do so (Meyer and Allen, 1991). The guiding criterion in the development of continuance commitment is self-interest, or, in the words of Heetderks
(1993): "what's best for me, rather than what's in the best interests of the organization."

The normative dimension of organizational commitment focuses on feelings of loyalty to a particular organization resulting from the internalization of normative pressures exerted on an individual (Popper and Lipshitz 1992; Hackett et al. 1994). Internalization occurs when the induced values of the individual and the organization are in congruence (O'Reilly and Chatman 1986). Consequent to the similarity of values, individuals exhibit committed behaviors because it is the right thing to do (Allen and Meyer, 1990). Employees who are normatively committed feel they ought to remain with the organization (Meyer and Allen 1991).

On the basis of their conceptualization, Allen and Meyer (1990) developed an instrument to measure organizational commitment along the three dimensions. The three-component measure was found to be psychometrically sound (Meyer et al. 1993). Factor analytic studies of the measure have shown that they measure three relatively distinct constructs (Meyer et al. 1993; Hackett et al. 1994). It has also been shown that the three dimensions of commitment correlate differently with variables purported to be antecedents of commitment (Shore and Tetrick 1991, Meyer et al. 1993). Table 2 summarizes the dimensions of organizational commitment and their respective items. 
Gadjah Mada International Journal of Business, September 2004, Vol. 6, No. 3

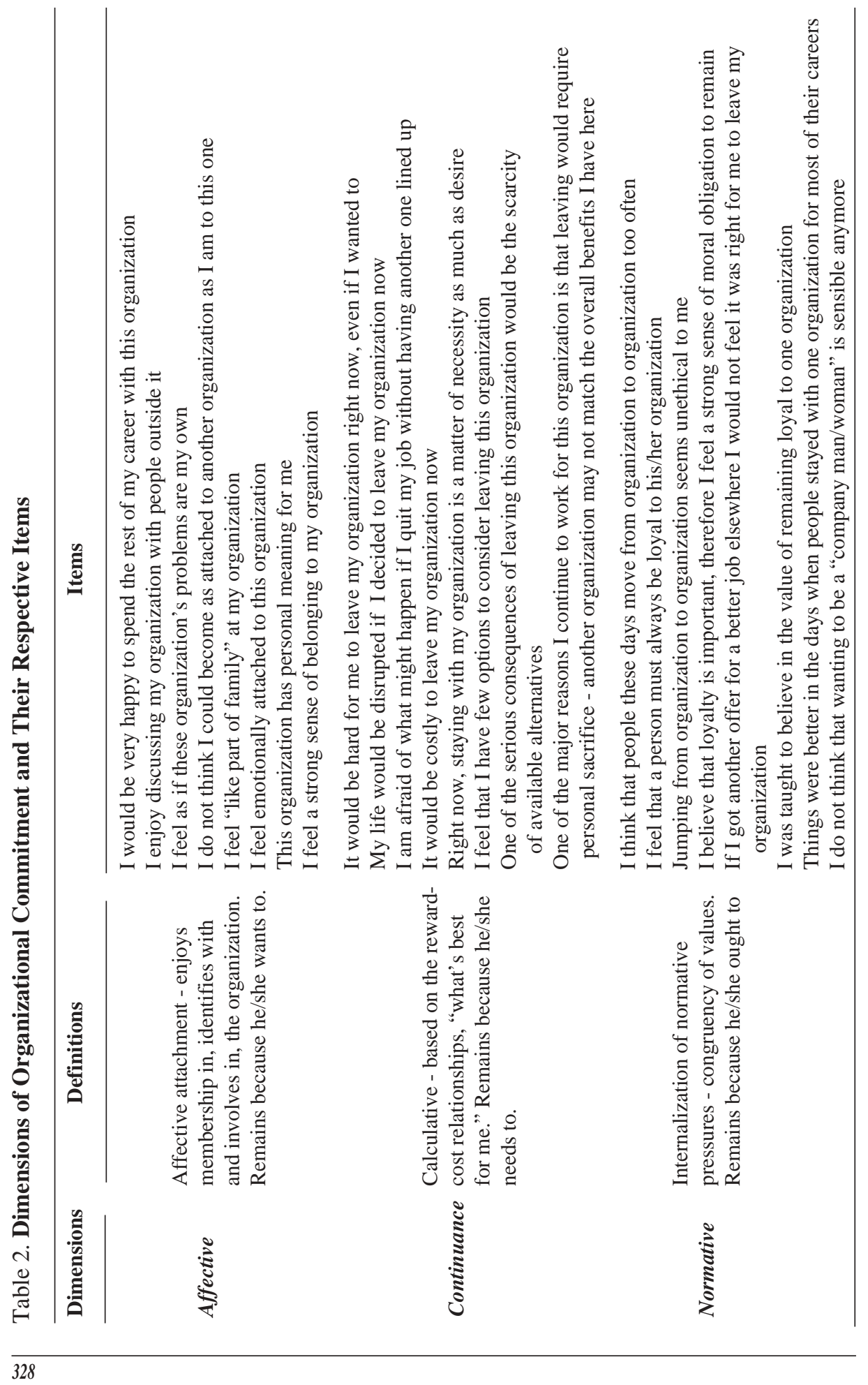


Zin -Perception of Professional Engineers toward Quality of...

\section{Method}

\section{The Sample}

The sampling frame used was public accountants in various private sector engineering-related firms in Malaysia. Two hundred and fifty (250) sets of questionnaires were mailed to the professional engineers which were randomly selected from the list provided by Malaysian Board of Engineers.

\section{Procedure}

A covering letter outlining the purpose of the study, defining the target sample, and the procedures of questionnaire distribution was enclosed. A total of 250 sets of questionnaires were sent to the organizations, and 152 usable questionnaires representing a response rate of 60.8 percent were used for statistical analysis.

\section{Results}

Measures of QWL and organizational commitment were factor analyzed, using varimax rotations, to determine their dimensions. Results of factor analyses indicated that the QWL measure was found to be consisted of seven dimensions, but the organizational commitment measure could be better represented by a four-factor model. The continuance commitment dimension is further divided into two subdimensions: high cost and lack of employment alternatives. The reliability coefficients of the QWL and organizational commitment sub-scales are reported in Table 3.

\section{The Effects of QWL on Organizational Commitment}

Table 4 presents results of regression analyses of QWL factors on the four dimensions of organizational commitment.

Table 3. Reliability Coefficients of QWL and Organizational Commitment SubScales

\begin{tabular}{cc}
\hline \multicolumn{1}{c}{ Scale } & Reliability (alpha) \\
QWL (overall scale) & 0.93 \\
Growth and development & 0.89 \\
Participation & 0.85 \\
Physical environment & 0.49 \\
Supervision & 0.79 \\
Pay and benefits & 0.84 \\
Social relevance & 0.70 \\
Workplace Integration & 0.79 \\
Organizational Commitment & \\
Affective & 0.85 \\
Normative & 0.84 \\
Continuance (cost) & 0.79 \\
Continuance (lack of alternatives) & 0.66 \\
\hline
\end{tabular}


Gadjah Mada International Journal of Business, September 2004, Vol. 6, No. 3

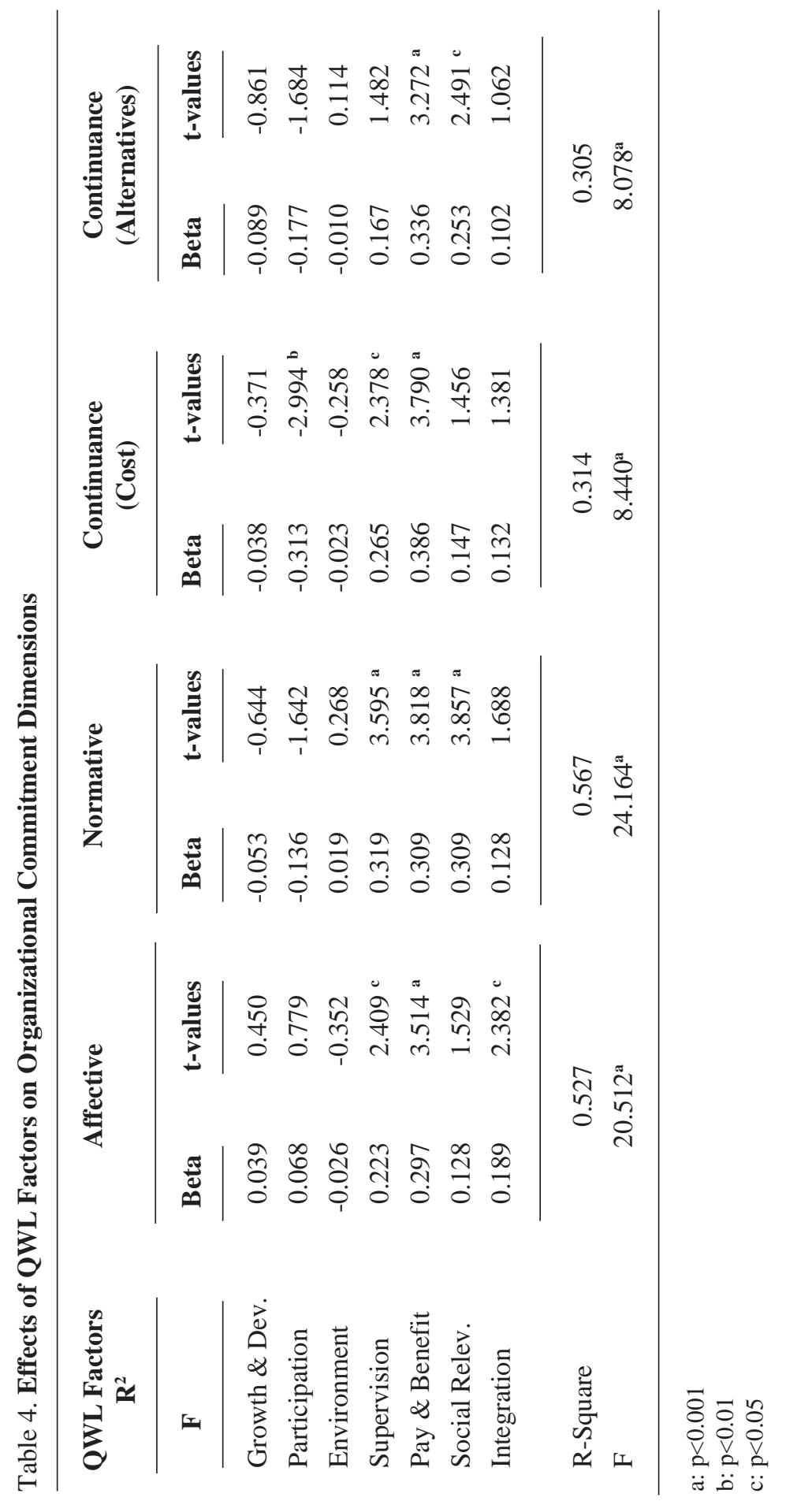


Zin -Perception of Professional Engineers toward Quality of...

\section{Affective Commitment}

-From Table 4 it is observed that the QWL variables account for about 53 percent of the total variance in affective com$\operatorname{mitment}\left(\mathrm{R}^{2}=0.527, \mathrm{~F}=20.512, \mathrm{p}<0.001\right)$. Three QWL factors are significant : supervision $(\mathrm{t}=2.409, \mathrm{p}<0.05)$, pay and benefit $(\mathrm{t}=3.514, \mathrm{p}<0.001)$ and integration $(\mathrm{t}=$ $2.382, \mathrm{p}<0.05)$.

\section{Normative Commitment}

The results show that the QWL variables account for about 57 percent of the variance in normative commitment $\left(\mathrm{R}^{2}=\right.$ $0.567, \mathrm{~F}=24.164, \mathrm{p}<0.001)$. Three QWL variables have significant effects on normative commitment: supervision $(\mathrm{t}=3.595$, $\mathrm{p}<0.001)$, pay and benefit $(\mathrm{t}=3.818, \mathrm{p}<$ $0.001)$ and social relevance $(\mathrm{t}=3.857, \mathrm{p}<$ $0.001)$.

\section{Continuance Commitment}

\section{(a) High Cost of Leaving}

The results show that the QWL variables account for about 31 percent of the variance in this type of commitment $\left(\mathrm{R}^{2}=\right.$ $0.314, \mathrm{~F}=8.440, \mathrm{p}<0.001)$. Three $\mathrm{QWL}$ variables have significant effects on this dimension of commitment: participation $(\mathrm{t}=-2.994, \mathrm{p}<0.01)$, supervision $(\mathrm{t}=$ $2.378, \mathrm{p}<0.05)$ and pay and benefit $(\mathrm{t}=$ $3.790, \mathrm{p}<0.001)$.

\section{(b) Lack of Employment Alternatives}

The results indicate that only about 31 percent of the variance in this type of commitment is accounted for by the QWL variables $(\mathrm{R} 2=0.305, \mathrm{~F}=8.078, \mathrm{p}<$ 0.001). Only two QWL factor, has significant effect on this dimension of commitment : pay and benefits $(t=3.272, p<$ $0.001)$ and social relevance $(\mathrm{t}=2.491, \mathrm{p}<$ $0.05)$.

\section{Discussion}

On one side, the findings of this research may provide some insights into the practice of effective management in Malaysia, especially in efforts to improve the quality of working life and organizational commitment among the professional engineers in Malaysia. The practice problem that this research addresses is timely, with the need to develop an understanding of quality of worklife and organizational commitment in Malaysian work environment.

Growth and development has been indicated by the respondents in this study as a significant antecedent of both affective and normative commitments. It is therefore suggested that, in order to develop a sense of commitment among the private sector organizations, efforts at providing more opportunities for the workers to develop their skills in the workplace should be undertaken. One such efforts might include providing more training opportunities to the government accountants. Training helps employees to improve the way they accomplish tasks to enhance their interpersonal and problemsolving skills. It is a mechanism through which members' contributions and resources may be maximized, especially in solving problems related to their work.

Pay and benefits has also been shown to be a significant antecedent of affective, normative and continuance (cost) commitments. It is not the actual pay that matters but the perceptions of the adequacy of their pay and benefits. These perceptions are probably formed out of the comparisons made with what their friends, with the same qualifications, are getting in other organizations. Monthly pay is only part of the reward system. Other benefits, such as fringe benefits and health care may be extended to employees to compensate for their willingness to work for lesser pay. 
Participation opportunities has significant positive relationship with affective commitment. As participation leads to involvement in the workplace, employees who perceive that they are given such opportunities would be more committed. This finding is consistent with the results obtained by Mottaz (1988) and Razali (1999) in their studies of determinants of organizational commitment.

This positive relationship could also be explained from perspective of the communication model of organizational commitment suggested by Gorden and Infante (1991). Participation, as operationalized in this study, includes opportunities for employees to contribute ideas to their supervisors. Participation, thus defined, can be viewed as an indicator of the presence of freedom of speech which was found by Gorden and Infante to be a positive predictor of organizational commitment. Participation by employees in decisions relating to their work would also allow them to have influence over work; this was found by Knoop (1994) to be positively related to organizational commitment. Increased participation and communication would allow employees to be better informed of the goals and values of the organization, leading to increased feelings of responsibility and job involvement (DeCotiis and Summers 1987). Professional engineers feel that participation is important in affecting their QWL.

The sample in this study comprises only professional engineers in selected private sector organizations in Malaysia. The work values (with regard to QWL and organizational commitment) among all employment categories in Malaysia therefore cannot be compared. Future research should include a much wider sample. This would allow comparisons be made on the effects of QWL on organizational commitment across occupational groups.

\section{References}

Allen, N. J., and J. P. Meyer. 1990. The measurement and antecedents of affective, continuance and normative commitment to the organization. Journal of Occupational Psychology 63: 1-18.

Camman, C. 1984. Productivity of management through QWL programs. In Strategic Human Resource Management edited by Frombun. New York: Wiley.

Chelte, A. F. 1983. Organizational commitment, job satisfaction and the quality of worklife. Unpublished Ph.D. Dissertation. Ann Arbor: UMI Dissertation Service, University of Massachussetts.

Cherns, A. B., and L. E. 1975. Assessment of the state of the art. In The Quality of Work Life edited by Davis and Cherns (vol. 1). New York: The Free Press.

Davis, L. E. 1977. Enhancing the quality of working life: Developments in the United States. International Labour Review 116: 53-65.

Davis, L. E., and A. B. Cherns. 1975. The Quality of Working Life (vol. 1). New York: The Free Press. 


\section{Zin-Perception of Professional Engineers toward Quality of...}

Decotiis, T.A., and T. P. Summers. 1987. A path analysis of a model of the antecedents and consequences of organizational commitment. Human Relations 40: 445-470.

Eisenberger, R., R. Huntington, S. Hutchinson, and D. Sowa. 1986. Perceived organizational support. Journal of Applied Psychology 71: 500-507.

Gorden, W. I., and D. A. Infante. 1991. Test of a communication model of organizational commitment. Communication Quarterly 39: 144-155.

Gowdy, E. A. 1988. The application of quality of work life research to human service management. Administration in Social Work 11: 161-174.

Hackett, R. D., P. Bycio, and P. A. Hausdorf. 1994. Further assessment of Meyer and Allen's (1991) three-component model of organizational commitment. Journal of Applied Psychology 79: 15-23.

Hackman, J. R., and E. E. Lawler. 1971. Employee reactions to job characteristics. Journal of Applied Psychology 55: 259-286.

Hackman, J. R., and G. R. Oldham. 1975. Development of the job diagnostic survey. Journal of Applied Psychology 60: 159-170.

Heetderks, T. D. 1993. What's best for me? An examination of calculative commitment and other calculative oriented variables. Unpublished Ph.D. Thesis. Wayne Ann Arbor: UMI Dissertations Services, State University.

Huse, E. F., and T. G. Cummings. 1985. Organizational Development and Change $\left(3^{\text {rd }}\right.$. ed.). St. Paul, Minnesota: West Publishing.

Knoop, R. 1994. Organizational commitment and individuals values. Perceptual and Motor Skills 78: 200-202.

Maccoby, M. 1984. Helping labour and management set up a quality of worklife program. Monthly Labour Review 107: 28-32

McGregor, D. M. 1960. The Human Side of Enterprise. New York: McGraw-Hill.

Meyer, J. P., N. J. and Allen. 1991. A three-component conceptualization of organizational commitment. Human Resource Management Review 1: 61-98.

Meyer, J. P., N. J. Allen, and I. Gellatly. 1990. Affective and continuance commitment to the organization: Evaluation of measures and analysis of concurrent and time-lagged relations. Journal of Applied Psychology 75: 710-720.

Meyer, J. P., N. J. Allen, and C. A. Smith. 1993. Commitment to organizations and occupations: Extension and test of a three-component conceptualization. Journal of Applied Psychology 78: 538-551.

Mottaz, C. J. 1988. Determinants of organizational commitment. Human Relations 41: 467-482.

Nadler, D. A., and E. E. Lawler. 1983. Quality of work life: Perspectives and directions. Organizational Dynamics 11: 20-30. 
O'Reilly, C. A., and J. Chatman. 1986. Organizational commitment and psychological attachment: The effects of compliance, identification and internalization on prosocial behavior. Journal of Applied Psychology 71: 492-499.

Popper, M. and R. Lipshitz. 1992. Ask not what your country can do for you: The normative basis of organizational commitment. Journal of Vocational Behavior 41: $1-12$.

Quinn, R. P., and G. L. Staines. 1979. The 1977 Quality of Employment Survey. Ann Arbor: University of Michigan.

Razali, M.Z.1999. Antecedents of organizational commitment and the effects on selected productivity_related outcomes among public employees in Malaysia. Monograph 5 . Sintok: University Utara Malaysia Publication.

Sayeed, O. B., and P. Sinha. 1981. Quality of working life in relation to job satisfaction and performance in two organizations. Managerial Psychology 2: 15-30.

Seashore, S. E., E. E. Lawler, P. Mirvis, and C. Cammann. 1982. Observing and Measuring Organizational Change: A Guide to Field Practice. New York: John Wiley.

Shore, L. M., and L. E. Tetrick. 1991. A construct validity of the survey of perceived organizational support. Journal of Applied Psychology 76: 637-643.

Stanley, D. 1986. Quality of work life index: Its development and validation. Unpublished Ph. D. Thesis. Ann Arbor: UMI Dissertation Service, University of Akron.

Stogdill, R. M. 1963. Manual for the Leader Behavior Description Questionnaire-Form XII: An Experimental Revision. Columbus : Ohio State University.

Taylor, J. C., and D. G. Bowers. 1972. Survey of Organizations: A Machine Scored Standardized Questionnaire Instrument. Ann Arbor: University of Michigan.

Vroom, V. H. 1960. Some Personality Determinants of the Effects of Participation. Englewood Cliffs: Prentice-Hall.

Walton, R. E. 1974. QWL indicators: Prospects and problems. In Measuring the quality of Working Life: A Symposium on Social Indicators of Working Life (March, pp: 1920) edited by A. H. G. Portigal. Ottawa.

Warr, P. B., J. Cook, and T. D. Wall. 1979. Scales for the measurement of some work attitudes and aspects of psychological well-being. Journal of Occupational Psycho0logy 52: 129-148.

White, T. A. 1981. The relative importance of work as a factor in life satisfaction. Relations Industrielles 36: 179-191.

Wilcock, A., and M. Wright. 1991. Quality of work life in the knitwear sector of the Canadian textile industry. Public Personnel Management 20: 457-468. 